\title{
Culture, Conservation and Crime: Regulating Ivory Markets for Antiques and Crafts
}

\author{
Alan Collins ${ }^{1}$, Caroline Cox ${ }^{2}$, Nick Pamment ${ }^{3}$
}

\author{
1 Economics and Finance Group, University of Portsmouth, UK \\ 2 School of Law, University of Portsmouth, UK \\ 3 Institute of Criminal Justice Studies, University of Portsmouth, UK
}

\begin{abstract}
Elephant population numbers are seriously declining due to poaching activity to provide illegal ivory for crafted items, sculpture and jewellery. Despite seemingly robust legislation controlling legal ivory sales (including export permit requirements for UK sales abroad) and the that fact that synthetic ivory can now be created to the same diagnostic standards as genuine ivory, selling at a fraction of the cost, the demand for the 'real thing' continues to rise in craft and antique markets with very few prosecutions in the UK. Moreover, there is evidence to suggest that "ghost ivory" (post 1947 worked ivory being sold as pre-1947 worked ivory) is being sold by traders to the unsuspecting and uneducated buyer. Two key illegal sub-markets are identified and a socio-legal and economic analysis of the regulatory options available is presented.
\end{abstract}

Key words: ivory, antiques, craft, regulation, poaching

\section{Introduction}

Ivory has been used as an artistic and cultural medium for millennia to create objects from the exotic and exquisite Chinese puzzle balls, Byzantine pyxis and Japanese Netsuke to household items such as knife handles, piano keys and billiards balls but ivory has a dark history and the killing of elephants for their ivory is not a modern day phenomenon. The Greeks and Romans had hunted the North African elephant to extinction more than two millennia ago with their use of the animals for warfare, ornament and as exotic entertainment to be slain by gladiators in the Roman arenas ( Alchin, L., 2015) (also see Walker, 2009). The Chinese elephant had met the same fate by 600BC (Ji Li et al, 
2012) and so it is not without due cause that modern day conservationists fear for the fate of the wild elephant population with recently reported figures from WWF stating that wild elephant numbers have declined from 1.3 million in 1979 to 600,000 in 1989 to an estimated 400,000 today (www.panda.org, 2015).

Ivory substantially features in the wildlife monitoring network TRAFFIC's estimate of the illegal trade in wildlife products. This trade is considered to be worth around one-third of the legal trade of $\$ 22.8$ billion, which would equate to a value of between $\$ 7.6$ and $\$ 8.3$ billion a year (TRAFFIC, 2015). The largest consumers of the illegal trade being China, the US and EU and the most lucrative specimens being traded are elephant ivory, rhino horn and tiger bones as well as birds and reptiles (Lawson \& Vines, 2014) (also see National Crime Agency, 2014).

The conservationists' warnings of wildlife population decreases to the point of near extinction has led to 181 countries ratifying the Convention on the Trade in Endangered Species (CITES). Hailed as "the Magna Carta for Wildlife" (Layne 2012), CITES subject wildlife imports to mandatory licensing and incorporates a banned list of prohibited species set out in its Appendix I and a "controlled list" list of species (Appendix II). The Convention was established to be implemented through Member Countries' national laws with each Member Country being tasked with reporting data back to a biennial CITES conference.

The UK, a founder member of the Convention, first legislated to give effect to CITES with the enactment of The Endangered Species (Import \& Export) Act 1976. This initial statute has been substantially amended and is now largely superseded by European Regulations. The Control of Trade in Endangered Species (Enforcement) Regulations 1997 (COTES) make provision for enforcement of the European Regulations and this is an evolving instrument and frames the legal regulations with which UK sellers of ivory must comply (Council Regulation EC No. 338/97 art 4.1 and 4.2). While COTES regulates trade offences once the species has entered the UK, the Customs and Excise Management Act 1979 ("CEMA") covers the illegal import and export of CITES species (Magistrates' 
Court Sentencing Guidelines, 2002). The current regulations state that for ivory to be legally exported or imported from or into the EU, an export and import permit is required from the designated (CITES) Management authorities of the export and import countries. These permits act as proof that the ivory was legally acquired and that the trade should not be detrimental to the survival of the species (CEMA, 1979).

This study serves to assess the regulatory context and options available to curb the activity in illegal ivory markets ranging from permissive to more prohibitive options. The paper is organized in the following manner. The next section considers the role and legal status of ivory within the antique trade. In section 3 some UK cases are then briefly examined to illustrate the limited efficacy of the current legal position in the UK in bringing about a substantial number of prosecutions for illegal ivory trading. The following section helps account for this limited success by establishing the range and complexity of the illegal sub-markets in ivory. Section 5 evaluates the range and applicability of various regulatory policy instruments ultimately seeking to help secure elephant populations in the face of an escalating recent onslaught of poaching activity. The final section offers summary and concluding remarks.

\section{Ivory and the Antiques Trade}

Within the EU, ivory can only be legally sold under certain conditions. It is generally forbidden to use Annex A-listed ivory for commercial purposes (Council Regulation (EC) No 338/97). However, sale of Annex A listed ivory is permitted if the intended use is non-commercial in nature and in addition to this exemption there is an antiques derogation that means "worked" ivory specimens acquired before 1 June 1947 do not require a certificate. The regulations state that specimens will be considered as worked if they are significantly altered from their raw state for jewellery, adornment, art, utility, or musical instruments, and need no further carving, crafting or manufacture to effect their purpose. In addition to this, as of the $9^{\text {th }}$ May 2013 to claim the derogation the item must also be worked across the whole surface. As an example, an antique carved netsuke of Shishi, the 
Chinese guardian lion created from a piece of tusk to depict Shishi in great detail will be able to claim the derogation, whereas a 19th century Anglo-Indian ivory dinner gong, like the one sold by Morphets Auction House in Harrogate, in November 2011 would no longer fall within the derogation.

Most antiques, enjoy this "worked item" derogation exemption from the CITES regulations, however, dealers and auctioneers need to be very clear about the law when they take in for sale or sell an ivory item as the timing of the working is vital. The CITES guidance (European Union Wildlife Trade Regulations, 2015) gives the following example: an ivory billiards ball made in 1900. As it was significantly altered from its original state (a raw tusk) to make the ball many years before the cutoff date of June 1947, it can therefore be legally sold within the EU without the need for a CITES certificate. The billiards ball would still come within the derogation if it had been re-carved, for example to make a walking stick handle, before June 1947. However, if the re-carving had been done after that date, it would be outside the derogation and need a CITES certificate from the department of Animal Health's Wildlife Licensing and Registration Service (Antique Trade Gazette, 2013). In May 2013, significant changes were introduced following new guidance from the European Commission on the interpretation of the "worked item" derogation and since then the "worked item" derogation does not apply to the import or export of items outside the EU. Anything sent by a UK antiques dealer to a buyer outside the EU will require an export permit (CEMA, 1979). Dealers have reported their confusion at the regulations as to the "worked item" derogation and leading UK solicitor, Andrew Banks of law firm Stone King who advises members of the antiques trade on CITES requirements has criticised DEFRA on its "wholesale failure" to make the trade properly aware of changes to the CITES regulations (Arkell, 2015).

In addition to COTES, ancillary legislation exists in the UK which, while not directly relevant to the illegal wildlife trade, is linked to it. The Proceeds of Crime Act 2002 and the Serious Crime Act 2015 
address offences which have been shown to facilitate the illegal wildlife trade, such as moneylaundering.

Despite the seemingly robust legislation and regulations controlling the sale of ivory and the fact that synthetic ivory can now be created to the same diagnostic standards as genuine ivory (Sims et al, 2011) and selling at a fraction of the cost, the demand for the "real thing" continues to rise. Moreover, there is evidence to suggest that sellers are using this to their advantage by passing off real (illegal) ivory as synthetic and indeed vice versa when they come to sell it (Sims et al, 2011).

As a consequence of these various rules, constraints and uncertainties the attainable sale prices for ivory objects have become unstable. In particular, the U.S. federal ban introduced in February 2014 has had an unsurprising detrimental impact on the prices of, in particular, high end ivory artefacts. The inability of dealers to take items to the U.S. to sell has unquestionably resulted in a drop in prices and a decline in the economies of specialist dealers (Macquisten, 2015). In addition to this, there can be little doubt that the fear of a total ban on the sale of ivory is also taking its toll on the legal trade in antique ivory items (Macquisten, 2015). Buyers are also understandably nervous about purchasing an object which may become illegal to re-sale. The current U.K. regulations have been accused of being anything but clear (Arkell, 2015) and this is perhaps best illustrated by the recent case against international auction house Christies. On the 23 May 2016, Christies were fined $£ 3,250$ for offering for sale an "unworked" ivory object, an un-carved tusk mounted on silver dating to 1880. The item was due to be offered at Christie's South Kensington sale on April 28, 2015 but following a tip-off to the Wildlife Crime Unit of the Metropolitan Police, the item was seized (Actman, 2016). In court, Christies' representatives apologised for what they called an "isolated incident". Contrary to some national press reports, this was not an issue of CITES licenses. The guidelines for the sale of "worked" items was revised by the CITES management authorities in December 2012, making an item such as the one offered for sale by Christies no longer subject to the 'worked item' derogation. The fact that the changes to the regulations were poorly advertised carried no weight with the court 
stating that, "Christie's professionals should know what they are doing and should be beyond reproach" (Capon, 2016).

\section{UK Cases}

It is an interesting fact that despite the calls for the sale of antique ivory to be outlawed, there have been only seventeen successful prosecutions ${ }^{1}$ against members of the antiques trade for the sale of illegal ivory under Regulation 8 COTES in the last twenty four years (TRAFFIC, 2015). However, this may not give a full picture of COTES offences particularly if viewed in light of the Elephant Trade Information System (ETIS) data. These figures show the UK to be playing an increasing role in the illegal ivory trade both at import and re-export but also as a transit country with reported seizures by the U.K. to ETIS between 2010 and 2014 to be 154 (averaging 30.8 seizures per year) with total seizures in the preceding five years being only seventy five (amounting to an average of 15 seizures per year). ${ }^{2}$

The antiques trade in the UK is disparate and diverse and includes the leviathans of the auction world such as Christie's, Bonham's and Southeby's, through high end dealers specialising in specific artefacts to general auction houses and dealers with a non-specific stock (of which ivory may be a part) to finally, the opposite end of the trade, 'car booters' and house clearance companies, with generally little knowledge of what they are selling. Educating and regulating this diverse population is challenging and whilst trade associations do exists, the fast majority of the trade do not belong to one.

COTES offences are notifiable to the Home Office however, statistical analysis of those offences under CITES is not possible as CITES offences have not been allocated a specific code and are, therefore, recorded under the general Home Office code "999/99 Other crime or record only entry not catered for elsewhere" (Environmental Audit Committee, 2012). In addition, as CITES offences

\footnotetext{
${ }^{1}$ See Appendix 1

${ }^{2}$ ETIS, managed by TRAFFIC, tracks illegal trade in ivory and other elephant products (https://cites.org/eng/prog/etis/index.php)
} 
are tried either in the Magistrates Court or the Crown Court (i.e. lower courts) they are not formally 'reported' and so do not appear on legal databases.

However, against this backdrop there have been two high profile cases involving the prosecution of an auctioneer and a dealer both of which occurred in October 2014.

The first case to come to court was that of R v Chiswick Auctions (William Rouse) [14 October 2014, Ealing Magistrates Court] which saw Chiswick Auctions fined $£ 3,200$ for the sale of a tusk carved to represent a train of elephants that came from an elephant killed during the 1960s. The successful prosecution followed an investigation by the Wildlife Crime Unit and Arts and Antiques unit officers during an on-going operation against modern ivory sales in London. Officers had discovered and seized the object from a Portobello Road Market dealer and their investigations tracked the item back to Chiswick Auctions. The prosecution, following the seizure of the item sent it for forensic testing which showed that the elephant had died after the 1947 cut-off date. The auction house's records showed that it had gone under the hammer for $f 100$. Although, the auction house pleaded guilty to the offence on October 14th 2014, stating that a senior auctioneer had made a mistake in the age of the item, Chiswick Auction's Managing Director, William Rouse spoke after the verdict of his shock at the size of the penalty "for an isolated incident that earned the auctioneers commissions of around $£ 40$ " and that he believed the auction house had been "harshly treated in response to a cause célèbre" finally stating that "a huge amount of public money has been spent on this matter but to what end? We are still permitted to sell antique ivory and what has it taught us apart from the need to be even more vigilant in a situation where every auction room in the land treads a difficult line?" (Arkell 2014). While Mr Rouse's attitude may not be shared by all of his fellow antiques professionals, dealers are quick to point out that while they find illegal elephant poaching abhorrent, they also consider the legislative rules and regulations confusing and difficult to follow. 
The second case ( $\mathrm{R}$ v Sara Wilkinson [20 October 2014 Isleworth Crown Court] involved a dealer, Sally Wilkinson of Chanticleer Antiques, who was charged with the sale of an ivory carving of a nude figure that police believed had been worked after June 1947. In contrast to the Chiswick Auctions case, here the prosecution did not send the item for forensic testing to date it definitively, rather they proceeded on the basis that it was up to the defendant to prove it was carved before 1947 . Ms Wilkinson, an experienced ivory dealer of more than 45 years, pleaded not guilty to the offence remaining firm in her assertion that the carving dated to the 1870s. Following her "Not Guilty" plea, the case was sent from Hammersmith Magistrate's Court to Isleworth Crown Court where the judge described placing the burden of proof on the defendant as "a bridge too far" (ATG Reporter, 2014). The prosecution, however, had already by then decided to withdraw the case.

Two issues that require addressing come out of these two cases. Firstly, there is clearly a need for a process to be in place to ascertain the age of ivory accurately and cheaply. The forensic testing undertaken by the prosecution in Chiswick case will have costs in the region of $£ 450+$ Value Added Tax (VAT), (Oxford Radiocarbon Accelerator Unit, 2015) against an item that had gone under the hammer for $£ 100$, making the auction house $£ 40$ in commissions. Secondly, the stance of the police in the Wilkinson case raises concerns about where the burden of proof should lie in such cases. The presumption of innocence is a corner stone of English law and the prosecuting authorities attempt to reverse this should concern the antiques trade.

The police and Crown Prosecution Service (CPS) have stated that in their view, future prosecutions should be brought on the basis that it is for the Defence to prove the age of the artefact in question - in other words, that a Regulation 8 offence should be prosecuted on a strict liability basis. In a CPS Memorandum of Understanding prepared following the collapse of the Wilkinson case, it concludes that "notwithstanding situations where a specimen's identity is obvious, the law provides that if a specimen is advertised, displayed or otherwise packaged as being/containing a controlled specimen, it shall be taken as such and the Crown is under no obligation, legal or otherwise, to prove its 
nature." This stance should be of concern to the antiques trade as it is a major departure from the current prosecution guidelines taking, as it does, the mens rea (or the intention or knowledge of committing the offence) out of the crime.

What is certain is the fact that currently little is known about the extent of trading in illegal ivory in the UK (IFAW, 2004). Despite the set of legislation at the law enforcers' hands, convictions seem to be few. This may be due to a variety of factors, including inter alia, a lack of resources available to the police and Border Force, a "soft" attitude by the judiciary or a lack of specialist knowledge. Alternatively it may be that the scale of the problem is already known but not easily identified.

\section{Disentangling the Illegal Market for Ivory}

The legal and trade context outlined above highlights the active functioning of a number of different illegal sub-markets for ivory and in which different mixes of regulatory policy instruments are likely to be appropriate. For the design of policy prescriptions and choice of regulatory instruments along the global supply chain then these illegal sub-markets may potentially be combined into two broad categories:

Category 1: Newly poached ivory - to make new craft items (openly to criminally complicit consumers or passed off as synthetic when suppliers and consumer know this is not so, or passed off as "ox bone" craft items (as may be found on eBay), (IFAW, 2004) or treated to make it appear old (pre-1947) with a view to making a sale on the legitimate antique market.)

Category 2: Post 1947 existing ivory craft items or ivory for crafting (passed off as pre-1947 or as ox bone) 


\section{Newly poached ivory}

For category 1, while CITES remains in place all international trade is illegal on conservation grounds. Thus the only testing required is to identify whether a tusk has been treated to appear to be pre1947 tusk. Such tests do exist and expert visual assessment can also be deployed to identify such artificial ageing (UNDOC, 2014).

From a legal, economic and ecological perspective it is a legitimate question to consider whether lifting the CITES international ban would stoke demand for new ivory or would it actually serve to reduce the incentive to poach by depressing market price, given a greater supply of ivory would legitimately come onto the market. Some consideration of this question is warranted, particularly as the status quo is characterised by a huge increase in poaching incidents and with wilderness areas, national parks, game reserves and conservation agencies in the main elephant hosting countries having very little revenue to protect herds beyond domestic sales ${ }^{3}$ from natural mortality and active conservation management. If demand is stoked substantially then trading will accelerate the path towards species extinction and even earlier sub-species extinctions. If the market price is depressed it may still only reduce the poaching effort expended for a relatively short time period. This is because in the longer run stocks of ivory will deplete given long reproduction cycles within elephant herds. Thus the replenishment rate to stocks may well be insufficient to meet even stable demand. Extinction of course may be a considered a desirable objective by those with large stocks of elephant ivory (Mason, Bulte, and Horan, 2012).

Making matters worse, however, we know that any price reduction effect is strongly subject to the usual ceteris paribus condition of stable demand. Unfortunately, we know that consumers strongly value authentic ivory over substitutes, such that demand is probably highly inelastic. Further there

\footnotetext{
${ }^{3}$ One might also observe that domestic sales in most countries where there are substantial elephant herds (e.g. Central and Southern Africa) are not likely to be supporting 'immediate domestic use', but rather are either held as speculative assets contingent on future CITES international trade ban lifting, or are held with a few to effecting illegal international smuggling (contravening CITES) in the near future to exploit high ivory prices in markets in East Asia and elsewhere.
} 
are rising real incomes and populations in China, Thailand and Laos such that market demand is growing (shifting rightwards) and that this growth is likely to be persistent. This means that lifting the CITES trade ban may not even lead to a significant price dip and could even coincide with price rises. Accordingly one cannot in any way confidently expect that on its own the simple act of lifting the CITES ban will automatically lead to lower poaching effort being expended and less elephants being slaughtered. Such simplistic thinking has been characterised by Ostrom, Janssen and Anderies (2007) and Ostrom and Cox (2010) as a "panacea problem". By this is meant "...a tendency, when confronted with pervasive uncertainty, to believe that scholars can generate simple models of linked social-ecological systems and deduce general solutions to the overuse of resources." [p1. Ostrom et al 2007]. One such 'simple' solution advanced has been to just permit legalized trading of ivory.

Past studies in the economic analysis and regulation of endangered species product markets have long entertained the possibility of some limited legalized trading in ivory to (i) provide some incentives for the sustainable management of elephants and (ii) on the demand-side to provide ivory users some access to limited supplies in order to reduce the incentive to push further underground a trade with smuggling and black market aspects (Barbier et al 1990, Bergstrom 1990). To combat such black market activity underpinned by wildlife poaching Kremer and Morcom (2000) advanced a solution predicated on the accumulation of a public stockpile of storable wildlife commodities. This would then enable the relevant government to threaten to dump them on the market if the extant population of the poached wildlife fell below a certain level. Essentially this might be labelled a timeconsistent stockpiling policy. A similar line of thinking was also articulated in the specific context of the conservation of black rhino (Brown and Layton (2001). Focussing more generally across all endangered species goods Fischer (2004) set out a simple model to explore whether limited legalized trade in otherwise illegal goods can be helpful for achieving policy goals like reducing poaching. Institutional and biological considerations were not really accorded any scrutiny in that economic analysis. 
For both ivory and rhino horn the key policy actors did, however, enact and sustain an outright ban via an 'Appendix 1' listing in the Convention on International Trade in Endangered Species of Wild Flora and Fauna (CITES) in 1973 and 1989. Stiles (2004) recorded how this led to unsustainably large elephant herd sizes in some Southern African countries alongside an inability to use the proceeds from ivory sales and sales of other by-products to directly finance conservation efforts. Hence, these countries continued to argue for the ban to be lifted. The possibility of this large herd size result for elephants was the subject of some earlier formal economic conjecture (Bulte and van Kooten 1996) but nevertheless, wildlife poaching of both elephants and rhinoceros has continued apace with black rhino pushed to 'critically endangered' status and white rhinos deemed to now be 'conservation dependent'. Stockpiles of ivory and rhino horn have, however, been accumulated across various Southern African countries and there is now much popular press and academic discourse calling for the lifting of trade bans in the face of continuing high levels of poaching (Scanlon, 2014). This pressure continued to build in the run up to the September 2016 CITES Conference of the Parties meeting which took place in Johannesburg, South Africa. In terms of the ivory trade, the meeting culminated in the conference adopting a non-binding resolution to close domestic ivory markets that contribute to poaching and the illegal ivory trade. The resolution sets out that it "recommends that all Parties and non-Parties in whose jurisdiction there is a legal domestic market for ivory that is contributing to poaching or illegal trade, take all necessary legislative, regulatory and enforcement measures to close their domestic markets for commercial trade in raw and worked ivory as a matter of urgency"(CITES, 2016). Although the resolution was unilaterally passed ay all 182 CITES members, there are fears amongst some conservation groups that the wording of the resolution enables countries that argue that their ivory markets do not contribute to poaching or the illegal trade to ignore it in practice. Time will tell and Japan immediately responded by stating that the resolution was not applicable to them for this reason. However the Chinese response has been more positive with the country stating by an official Press Announcement on the $30^{\text {th }}$ December 2016 that it will close its domestic ivory market (with the exemption of antique ivory) by the end of 2017. What 
remains of concern to conservationists is the position of Hong Kong in the illegal ivory trade chains remains the same. Here there have been no announcements as to accelerating the closure of the domestic market. Cheryl Lo, a senior wildlife crime officer with WWF explained the groups concerns saying that "With China's market closed, Hong Kong can become a preferred market for traffickers to launder illegal ivory under cover of the legal ivory trade" (The Guardian, 2016).

Notwithstanding the 2016 CITES meeting and in the aftermath of a huge increase in elephant and rhino poaching incidents in Central and Southern Africa in recent years, increasingly the emphasis of work on policy options has been on a need to change tack and try different policy solutions. This is the current context given that maintaining the business-as-usual regulatory and policy context does not seem able to adequately obstruct the path towards sub-species and eventually species extinction. More recently Biggs et al (2013) argued for the necessity of such a radical proposal in tandem with some measure of regulatory activity harnessing existing technology able to discern the provenance of the rhino horns. The intention is to help obstruct 'laundering' of illegal ivory/rhino horn and the practice of illegal trading. Arguably this and other work is overly confident on the scope for relying on technology in isolation to resolve the poaching problem and neglects consideration of the basic organizational architecture and market institutions that would need to evolve to support sustainable trading. These and some other points were set out in a short response to that work (Collins, Fraser and Snowball 2013) and subsequently expanded in Collins, Fraser and Snowball (2015).

That work seems to raise many awkward questions for regulatory design rather than provide comprehensive answers supported by clear direct evidence. Furthermore, the setting of that work has already been somewhat overtaken by events. Following a court judgement in late November 2015 (BBC News 2015), South Africa has now lifted the ban on the domestic trading of rhino horn in South Africa overturning a moratorium on the trade imposed by the South African Government in 2009. This decision has potentially strong repercussions for ivory trading elsewhere in Central and 
Southern Africa. This legal judgement was founded on two reasons, namely, lack of public consultation before the ban was invoked and a failure to stem the poaching crisis with the ban in operation.

The reasoning for the judgement is open to question given that public consultation is clearly not always clearly present in all other examples of such public decision-making in South Africa. Furthermore, the implied legal explanation for the poaching crisis (i.e. lack of public consultation and high levels of poaching in the post-ban period) seems overly simplistic set against the more nuanced and multidimensional reasoning offered in Collins, Fraser and Snowball (2016).

\section{Post 1947 existing ivory craft items or ivory for crafting}

For category 2 ivory there are discernible attempts to pass off as pre-1947 ivory and also to pass of via e-bay and other distribution channels as 'ox bone'. The term 'ox bone' has become a generally understood code for ivory to bypass trading sanctions. Consumers of ox bone items would likely be very dissatisfied if they actually received ox bone and would likely not rate the supplier highly on eBay. This would impact on their trading reputation and business longevity. Perry (2014) notes that eBay 'banned' all ivory sales after an investigation by the International Fund for Animal Welfare exposed how 2,275 elephant ivory items were sold in a single week in 2007 . However, sellers bypass the ban by using the label of ox bone or other terms. If ox bone trading was banned then another term or label would doubtless emerge to skirt round any eBay regulations. Further, even if all antique trading was banned on eBay other trading sites would inevitably emerge to meet the demand for such a trading market to operate (IFAW, 2014).

\section{Regulatory Context and Regulatory Instruments}

In considering how to address illegal ivory trading there are a number of regulatory options but the ambit and scope of their applicability is predicated on the relevant institutional, jurisdictional, ecological and geographical context as well as a number of mundane practical concerns. 
Investigations of eBay for category 2 illegal ivory trading can be done by trade inspectors and police using agent provocateur and 'sting' tactics but this would need to be done continuously or with major resource-intensive large scale operations to have a discernible impact. Actually selling ox bone would reveal some buyers identities who might be frightened into refraining from subsequent illegal purchases via warning letters. Hitherto, no such attempts have been made via this warning letter approach, thought it has been tried in the context of music and film internet piracy with relatively little success (Green 2014).

In terms of category 1 illegal ivory sales we know that after the 1989 CITES international trade ban that the overall population of elephants in the African continent substantially increased. Despite this outcome, analysis of elephant population data over the period 1979-2007 shows that within some 37 African countries elephant numbers were still being lost. Lemieux and Clark (2009) suggest that this is largely explained by the degree of regulatory efficacy. Within these 37 countries there was deemed to be present (despite CITES) what effectively comprise unfettered and unregulated ivory markets. Their presence eases the conduct of both illegal domestic and international trading. As such in accordance with the standard Becker supply of crime model (Becker 1968) merely announcing the imposition of a full trade ban will not guarantee full compliance. To support such a ban there must also be strong enforcement resources visibly present, else a low probability of arrest and conviction is signalled and factored into criminal decision-making. In turn this leads to a higher expected rate of return from poaching and thus more poaching effort expended.

It is straightforward to advance plausible reasons for why regulatory laxity in this specific environmental context may be found. First, all of these 37 countries are 'less developed countries' with low GDP per capita, high infant mortality, low school enrolment and in many cases nutrition and food security issues. Against such a macroeconomic backdrop, public spending for wildlife protection may not be given the priority it deserves, particularly when looking from a more global environmental resource conservation perspective. Accordingly, international cooperation and 
resource transfers are necessary (though not sufficient) to reduce poaching and reverse elephant population decline in the short to medium term. Secondly, institutional quality matters. Many of these countries feature what Acemoğlu and Robinson (2012) would describe as weak or eroded institutional quality typified by democratic deficiencies, high levels of political, public and corporate corruption, weak oversight of public expenditure disbursement, a small and diminishing tax base and low trust in police and judicial processes.

In this context illegal trading is more readily able to be sustained. Institutional quality also has a direct bearing on the willingness to monitor elephant killings and to help track illegal trading as mandated by CITES (CITES: $3^{\text {rd }}$ March 1973). This provides baseline information and local statistical data to inform any targeted regulatory enforcement.

These general regulatory imperatives condition the geographical applicability of any specific regulatory policy instrument. For example, as Bennet (2015) discusses in the context of the potential establishment in some circumstances of controlled legal trading in ivory, robustly credible and transparent systems (to obstruct potential governmental corruption) would need to first be set in place. Only then might it be possible to firmly guarantee that ivory from illegally killed elephants could not be laundered on any legal market.

One of the circumstances under which controlled legal ivory trading might be permitted is in the context of allowing episodic or 'one off' trades of illegal ivory seizures or ivory from natural mortality and active conservation management. The rationale here is that such trades might help provide revenue to finance conservation effort (Scanlon, 2014). Again robust and transparent systems would need to already be in place to detect attempts at laundering ivory sourced beyond seizures, natural mortality and conservation management. Similarly transparency is needed to ensure that the resultant revenues are manifestly directed to supporting conservation efforts and not enriching participants in corruption. 
Advocates of such episodic or one off sales have not remained unchallenged. In large part this relates to understandable conservationist antipathy to effectively buttressing the supply chain serving previously (and potentially contemporaneously) illegal consumers. Elements of this supply chain comprise people with links to, or actual members of, criminal syndicates and rebel militias (engaged in many other criminal markets and enterprise). As such for some conservationists it is highly distasteful and potentially dangerous to tacitly or explicitly work with them, as it proffers some measure of respectability on such individuals. It should be noted that fighters of the 'Lord's Resistance Army' (LRA) were identified and formally sanctioned by the United Nations Security Council in 2014 for illegal hunting and ivory trading, especially in central Africa.

More fundamental policy and operational objections to such trades relate to their possible undesirable economic effects, which have prompted some countries to publicly burn or crush seizure stockpiles (see Zane 2016) in the full glare of media scrutiny. Scriber (2014) contends that these undesirable economic effects arise from confusion about the prospect of more one off legal ivory trades. He argues that this has helped to boost speculative poaching motives, thus sustaining relatively high black market prices and encouraging high levels of actual poaching effort. Suggesting such a direction of causality is an entirely legitimate and logically plausible assertion. Ideally this would be subjected to independent empirical scrutiny but inevitably such a task is hindered by black market prices series not being readily available. It also remains plausible that game farm and hunting lobbyists as well as government corruption might also try to raise the frequency of such one off trades such that they occur even when they are not biologically warranted. Such charges have also been levelled against Zimbabwe in the context of legal (under CITES) stock export sales justified on the basis of guarding against elephant overpopulation, even when population estimates have been strongly disputed (Teagle 2015).

With the CITES status quo in place for both category 1 and 2 illegal sub-markets and assuming willingness for reasonable international cooperation and strong institutional quality in place, a mix of 
more narrowly focussed regulatory policy instruments can be actively considered at various points of intervention along the illegal supply chain. Applied singularly they are unlikely to prove effective in arresting the decline of elephant numbers and avoiding species extinction. Some of these policy instruments are considered below.

Improved cross country intelligence gathering on the criminal gangs is clearly vital but in terms of addressing on-the-ground poaching one immediate measure that is being undertaken in some country contexts such as Kenya is to raise deterrence levels far higher. This has been done by effectively legitimising a shoot-to-kill policy when engaging poachers. This seems draconian but in truth many poachers are better armed and equipped than rangers so that ambush surprise tactics do help rebalance the rules of engagement. Unfortunately this policy does not usually involve the criminal kingpin responsible but can make their operations more costly. Yet kingpins are often protected by front men and a lack of extradition agreements between some countries. Collins, Fraser, Snowball 2016 note work that points out that there is no shortage of low income and unemployed men willing to joining wildlife poaching trips, so that anti-poaching patrols and rangers must be well resourced and active throughout the current onslaught of poaching and beyond to ensure continuing deterrence. The problem is compounded by truly remote wild herds in central Africa being significant to species survival as well as herds in national parks and private reserves which are somewhat easier assets to protect.

At the level of consumers, education to adults and children about the need for sustaining wildlife and biodiversity is a laudable measure but sadly likely to be very slow to realise sufficiently rapid returns in terms of arresting elephant population decline and difficult to attribute to it any component of decline should it occur. A more direct but perhaps riskier intervention would be to sanction flooding the market with synthetic or fake ivory and ivory substitutes. There are many antique dealers who feel confident in discerning authenticity but these may not always be available 
for consultation in some bilateral trades. There also remains the open empirical question as to whether such market flooding would inadvertently stoke currently latent demand.

With a modified CITES agreement in place to allow some regulated market institutions to develop under the scrutiny of international governmental scrutiny and international wildlife bodies (to ensure no illegal ivory laundering) then the speculative poaching motive from 'one off' or episodic sales maybe reduced and revenue from tusk sales fully recycled to support conservation efforts and fund ranger and anti-poaching patrols in countries without the economic resources to adequately fund them. Eventually over time a single internationally regulated supply chain may displace and through scale economies price out of the market the well-established criminal syndicate supply chain networks. Yet learning from other criminal networks where revenue streams are challenged in this way (such as drug gang turf wars) suggests it is likely to be accompanied by violence, sabotage and bloody conflict in the short term. This would need to be resisted by well-resourced police and ranger services. The illegal ivory supply chain will not just quietly and conveniently disappear.

\section{Summary and Concluding Remarks}

Elephant population numbers are seriously declining and if the rate of decline continues sub-species and species extinction in the coming decades are real possibilities. This decline is fuelled by poaching activity to provide illegal ivory for crafted items, sculpture and jewellery. Despite the operation of a high profile international trade ban agreement - CITES -poaching activity has recently accelerated and the number of prosecutions in ivory markets such as the UK remains surprisingly very low indeed. The reasons for this poor prosecution rate are considered in the context of the regulatory complexities associated with two broad categories of illegal sub-markets.

The British government has committed itself to tackling the illegal trade in wildlife and to date have implemented strategies including the Illegal Wildlife Trade (IWT) Challenge Fund and Darwin Fund administered by DEFRA, both of which are aimed at tackling the trade at source. The UK 
Conservative Party have, in successive manifestos pledged to extend policy to include looking at the closing of home markets - this being most recently mooted in Andrea Leadsom's September 2016 announcement regarding the ban on the sale of modern ivory and her commitment to a consultation regarding the introduction of "documentary proof" for the sale of antique ivory. ${ }^{4}$ Whilst it is not suggested that the auction rooms and antiques shops of the U.K. are regularly selling modern "fresh" ivory as there is certainly no evidence for this, there are concerns that part of the antiques trade are selling post 1947 ivory as pre-1947 pieces.

During the course of this study the authors met several highly specialist and knowledgeable dealers and auctioneers who had proven risk assessment strategies in place for the assessment of ivory which they followed closely (Cox, 2017). However, we also witnessed deals at small fairs and car boot sales where dealers showed little or no knowledge of the item they were selling. One example of this would be witnessing a car boot sale dealer assure a potential buyer of an ivory bangle that she could tell it was antique because it had been tested. When the buyer asked how it had been tested the dealer said she had "put a hot pin in it". This may have indicated the material but it would not have given any indication as to age or legality. Whilst all the dealers we spoke to referred to the 1947 cut-off date and to the recent cases involving members of the antiques trade, when asked about the current law they also stated that they found DEFRA's guidance to be unclear and unhelpful. Any future policy decisions from DEFRA ideally ought to avoid this type of confusion in the future.

In terms of how the British antiques trade assesses an ivory item prior to offering it for sale every dealer consulted by us said that they used their "knowledge and experience" to assess ivory which came into their possession. We defined "knowledge and experience" as an assessment of the colour of the item, the quality of its carving, etc. In terms of a risk assessment strategy while it may be valid it is also difficult to regularise and legislate for such 'assessments'. Dealers and auctioneers used

\footnotetext{
4 "Documentary proof" has as yet not been defined and details of the consultation process are still awaited from DEFRA.
} 
phrases like: "you know it when you see it". In terms of creating a sound risk assessment strategy for members of the trade whilst the appraiser's knowledge will inevitably play a part given the potential for gaps in an individual's knowledge or the chance of misidentification is should not be all that is relied on. Some of the dealers and auctioneers we consulted also used other tools to supplement their professional knowledge including carrying out additional research regarding the items (for instance investigating its provenance). However, none of the dealers or auctioneers we consulted used scientific testing as a means of authenticating an item for sale. With scientific testing currently costing more than the value of many items being offered for sale it is not surprising that the trade are not using this method of assessment. The train of elephants sold in the Chiswick case went under the hammer at $\mathrm{f100}$. The costs of testing in a commercial laboratory would have been in excess of f400. If, therefore the British government are considering incorporating scientific testing into the "documentary proof" to be provided before ivory can be sold by the antiques trade, this will require serious consideration. How the trade view their risk assessment strategies going forward is important and it is also something that policy makers will need to consider in writing their new guidelines as to what will constitute "documentary proof" as to the age of an ivory item.

One potential response to the issue may be the so-called "ivory passport" system which has been suggested by several parties (Chesters, 2016). It is suggested that such a passport would replace the current Article 10 certificate and remain (unlike an Article 10 certificate) with an item for ever. The item could not be sold without its accompanying passport, which would, rather like a car log book, would record past owners and provenance as well as details descriptions and photographs of the item. Interviewees suggested that this would be a more accurate and safe system than the current Article 10 certificate which, they suggested was open to abuse because it its lack of robust items categorisation and description. It is suggested that the cost of a passport would be higher than that of the Article 10 certificate, with figures in the hundreds of pounds however, an item would only need to acquire it once. 
As with scientific testing, however, while such a system may be acceptable to dealer sand auctioneers selling high value ivory items, it does not deal with the thousands of low value pieces routinely seen at fairs, car boot sales and shops routinely changing hands for tens of pounds.

Finally, the issue of compensation for dealers and collectors of ivory in the event of a complete closure of the U.K.'s domestic ivory market should be considered. This "nuclear option" could see owners, dealers and collectors of ivory receiving the cash value of their item in the event of them becoming illegal to sell (Cox, 2017). Whilst this may be an acceptable proposition to parties who would suffer a financial loss as a result of a total ban it is difficult to see that it is something to which the government would wish to commit. It does however undoubtedly leave buyers of hitherto legal items at a considerable financial disadvantage. However, this type of situation is not without precedent. Following "The Public Inquiry into the Shootings at Dunblane Primary School on 13 March 1996" conducted by Lord Cullen (Cullen, 1996) the British Government instigated a ban on the public ownership of hand guns in the U.K. Following the ban, the government established a $f 150$ million program to compensate handgun owners for firearms that they handed in to police stations during an amnesty period that ran from July 1997 through February 1998. That being said, if BADA are correct in their estimation of their being in excess of two million ivory items in British homes the compensation pot would need to be considerable larger than that established following the Cullen Report.

It is argued that there is no single panacea that would address this environmental resource problem so that a mix of policy instruments should be considered. For newly poached ivory the need for international cooperation, resource transfers and measures to improve institutional quality are considered to be essential pre-requisites to ensure the efficacy of any specific regulatory instrument. Such instruments may be applied at various stages of the supply chain, some of which are likely to vary in terms of the speed of their potential impact in arresting the decline of elephant population numbers. 
For the trade in ostensibly 'post-1947 existing crafted ivory' web auction platforms are the key conduit in the UK and elsewhere for supporting this illegal trading. Continuous monitoring and enforcement, though resource intensive is considered the only practical means for addressing such wildlife crime. Internet trade bans are easily subverted and new, less visible auction trading platforms may easily emerge.

Ultimately to address category 1 and category 2 illegal sub-markets, conservation efforts and elephant herd protection must be funded. One-off or episodic stockpile sales from seizures, natural mortality and active conservation management may provide occasional cash injections to support conservation and protection activities and salaries but not on a necessarily continuous basis. They may also have unintended consequences in stoking speculative poaching activity. Accordingly, revisiting the necessary institution building to support the development of a permanent regulated supply chain is urgently warranted. In this way conservation and protection related salaries and operations could be funded on a continuous sustainable basis. It is acknowledged, however, that the supply chains of criminal syndicates will not quietly be displaced such that a short term spike in violence, sabotage and poaching effort should be an expected response and well-resourced resistance needs to be set in place first.

\section{References}

Acemoğlu, D. and Robinson, J., 2012. Why nations fail: the origins of power, prosperity, and poverty. Crown Business: MA, USA.

Actman, J. (2016). 'Christie's Auction House Fined After Trying to Sell Ivory'. National Geographic. Retrieved from: http://news.nationalgeographic.com/2016/05/christies-auction-house-fined-sellingivory/ [Date accessed 08/05/2016] 
Agence France-Presse, (2016). China to ban ivory trade by the end of 2017. The Guardian. [online] Available at: https://www.theguardian.com/environment/2016/dec/30/china-ban-ivory-trade-2017elephants-wwf [Accessed 1 Feb. 2017].

Alchin, L. (2015). "Wild Animals at the Colosseum". Retrieved from:

http://www.tribunesandtriumphs.org/colosseum/wild-animals-at-the-colosseum.htm. [Date accessed 02/04/2016]

Arkell, R. 2014. Auction House fined $\mathrm{f3200}$ over ivory breach, Antiques Trade Gazette retrieved from http://www.antiquestradegazette.com/news/2014/oct/20/auction-house-fined-3200-over-ivorybreach/ [date accessed: 25/04/2016]

Arkell, R. (2015). 'Lawyer slams DEFRA over CITES chaos.' The Antiques Trade Gazette, Issue 2198, 13

Arkell, R. (2015). 'Lawyer slams DEFRA over CITES chaos.' The Antiques Trade Gazette, Issue 2198, 13

The Antiques Trade Gazette (2013) ‘Endangered Species'.

https://www.antiquestradegazette.com/guides/information-guides/endangered-species/ [date accessed 08/06/2016]

ATG Reporter (2014) 'Asking Portobello dealer to prove age of ivory carving is "a bridge too far" says judge', Antiques Trade Gazette. http://www.antiquestradegazette.com/news/2014/nov/25/askingportobello-dealer-to-prove-age-of-ivory-carving-is-a-bridge-too-far-says-judge/. [Date accessed: $26 / 08 / 2015)$

Barbier, E., Burgess, J., Swanson, T. and Pearce, D. 1990. Elephants, Economics and Ivory. London: Earthscan. 
BBC News (2015) South Africa lifts ban on domestic rhino horn trade, November $26^{\text {th }}$ http://www.bbc.co.uk/news/world-africa-34914154 (date last accessed 02/01/2016)

Becker, G. S. 1968. Crime and punishment: An economic approach. Journal of Political Economy, 76(2), 169-217.

Bennett, E.L., 2015. Legal ivory trade in a corrupt world and its impact on African elephant populations. Conservation Biology, 29(1), pp.54-60.

Bergstrom, T. 1990. Puzzles: On the economics of crime and confiscation. Journal of Economic Perspectives, 4(3), 171-178.

Biggs, D., Courchamp, F., Martin, R., and Possingham, H. P. 2013. Legal trade of Africa's rhino horns. Science, 339(6123), 1038-1039.

Brown, G., and Layton, D. F. 2001. A market solution for preserving biodiversity: The black rhino. In: J. Shogren and J. Tschirhart (eds), Protecting Endangered Species in the United States: Biological Needs, Political Realities, Economic Choices (pp. 32-50). Cambridge: Cambridge University Press.

Bulte, E. H. and van Kooten, G. C. 1996. A note on ivory trade and elephant conservation. Environment and Development Economics, 1(4), 433-443.

Capon, A. (2016) 'Christie’s fined $£ 3250$ for offering 'unworked’ elephant ivory trophy'. Antiques Trade Gazette. Retrieved from: https://www.antiquestradegazette.com/news/2016/christie-s-fined3250-for-offering-unworked-elephant-ivory-trophy/ [Date accessed 08/06/2016]

Chesters, L. (2016) 'Antiques trade will have input to ivory rule changes', Antiques Trade Gazette, 27 September. Retrieved from: https://www.antiquestradegazette.com/news/2016/antiques-tradewill-have-input-to-ivory-rule-changes/ [Date accessed 10/01/2017]

Convention on international trade in endangered species of wild fauna and flora (2016) draft decisions and amendment to resolution conf. 10.10 (rev. Cop16) on trade in elephant specimens. 
Collins, A., Fraser, G., and Snowball, J. 2013. Rhino poaching: supply and demand uncertain. Science, 340 (6137), 1167.

Collins, A., Fraser, G. and Snowball, J. 2015. Issues and concerns in developing regulated markets for endangered species products markets: The case of rhinoceros horns Cambridge Journal of Economics, 40 (6), 1669-1686.

Council Regulation (EC) No. 338/97 art. 4.1 and 4.2. Retrieved from:

http://ec.europa.eu/environment/cites/info_permits_en.htm (date accessed 03/04/2016)

Council Regulation (EC) No 338/97 (OJ No L 61, 3.3.97, p. 1. Retrieved from: http://eurlex.europa.eu/legal-content/en/ALL/?uri=CELEX\%3A31997R0338. [Date accessed 08/05/2016]

Cox, C. 2017. The Elephant in the Sale Room - An inquiry into the U.K. antiques trade's sale of ivory. Draft report. 2017.

Cullen, T. (1996). The Public Inquiry into the Shootings at Dunblane Primary School on 13 March 1996. [online] The Stationery Office. Available at:

http://lx.iriss.org.uk/sites/default/files/resources/025.\%20The\%20Cullen\%20Inquiry\%20Report\%20i nto\%20the\%20Shootings\%20at\%20Dunblane.pdf. [Accessed 1 Feb. 2017].

Customs and Excise Management Act 1979 (1979). Retrieved from http://www.legislation.gov.uk/ukpga/1979/2/contents. [Date accessed 08/06/2016] Environmental Audit Committee, 2012. Wildlife. http://www.publications.parliament.uk/pa/cm201213/cmselect/cmenvaud/140/14007.htm. EC.europa.eu. (2017). The European Union and Trade in Wild Fauna and Flora - Environment European Commission. [online] Available at: http://ec.europa.eu/environment/cites/legislation_en.htm [Accessed 1 Feb. 2017]. 
Fischer, C. 2004. The complex interactions of markets for endangered species products. Journal of Environmental Economics and Management, 48(2), 926-953.

Green C. (2014) New internet piracy warning letters rules dismissed as 'toothless' 23rd July, The Independent, $\quad$ http://www.independent.co.uk/life-style/gadgets-and-tech/news/new-internetpiracy-warning-letters-rules-dismissed-as-toothless-9623907.html

International Fund for Animal Welfare (IFAW), 2004, "Elephants on the High Street: An investigation into ivory trade in the UK". Retrieved from http://www.ifaw.org/united-states/node/6338 [Date accessed 10/06/2016]

International Fund for Animal Welfare (IFAW), 2014. Wanted - Dead or Alive Exposing Online Wildlife Trade. IFAW, p.20.

Li, J., Hou, Y., Li, Y. and Zhang, J. (2012). The latest straight-tusked elephants (Palaeoloxodon)? “Wild elephants" lived 3000 years ago in North China. Quaternary International, (281), pp.84-85.

Kremer, M. and Morcom, C. 2000. Elephants. American Economic Review, 90(1), 212-234.

Lawson, K and Vines, A. (2014) 'Global Impact of the Illegal Wildlife Trade - The Costs of Crime, Insecurity and Institutional Erosion', Chatham House. Retrieved from: org/sites/files/chathamhouse/public/Research/Africa/0214Wildlife.pdf [date accessed: 02/04/2015] Layne, E.N., 1973. Eighty Nations Write Magna Carta for Wildlife. Audubon Magazine, 75(3), p.99. Lemieux, A.M. and Clarke, R.V., 2009. The international ban on ivory sales and its effects on elephant poaching in Africa. British Journal of Criminology,49(4), pp.451-471.

Macquisten, I. (2015) 'UK ivory ban would destroy my business'. Antiques Trade Gazette. Retrieved from: https://www.antiquestradegazette.com/news/2015/uk-ivory-ban-would-destroy-mybusiness/ [Date accessed 08/05/2016] 
Magistrates' Court Sentencing Guidelines: Sentencing for Wildlife Trade and Conservation Offences, November 2002. Retrieved from http://www.eurocbc.org/wildlife_guidelines.pdf. [date accessed 08/05/2016]

Mason, C.F., Bulte, E.H. and Horan, R.D. (2012) 'Banking on extinction: endangered species and speculation', Oxford Review of Economic Policy, 28(1), p. pp. 180-192.

National Crime Agency, (2014). 'National Strategic Assessment of Serious and Organised Crime'. London: National Crime Agency. http://www.nationalcrimeagency.gov.uk/publications/207-ncastrategic-assessment-of-serious-and-organised-crime/file [date accessed: 02/04/2015)

Ostrom, E., Janssen, M.A. and Anderies, J.M., 2007. Going beyond Panaceas. Proceedings of the National Academy of Sciences, 104(39), pp.15176-15178.

Ostrom, E. and Cox, M., 2010. Moving beyond panaceas: a multi-tiered diagnostic approach for social-ecological analysis. Environmental Conservation, 37(04), pp.451-463.

Oxford Radiocarbon Accelerator Unit: "Radiocarbon Dating for Art History", Oxford University. Retrieved from: https://c14.arch.ox.ac.uk/embed.php?File=leaf_art.html [Date accessed 10/06/ 2016]

Perry, K. 2014. Ivory traders using eBay to sell goods. The Daily Telegraph.

http://www.telegraph.co.uk/technology/internet/10629910/Ivory-traders-using-eBay-to-sellgoods.html [date accessed 12/o5/2016]

Proceeds of Crime Act (2002) www.legislation.gov.uk/ukpga/2002/. [Date accessed 08/05/2016]

Scanlon, J. (2014). 'CITES and confiscated elephant ivory and rhino horn - to destroy or not destroy?', Retrieved from http://voices.nationalgeographic.com/2014/10/20/cites-and-confiscatedelephant-ivory-and-rhino-horn-to-destroy-or-not-destroy/ 
Scriber B. 2014. 100,000 Elephants Killed by Poachers in Just Three Years, Landmark Analysis Finds

Central Africa has lost 64 percent of its elephants in a decade. National Geographic AUGUST 18, 2014 http://news.nationalgeographic.com/news/2014/08/140818-elephants-africa-poaching-citescensus/

Serious Crime Act (2015) www.legislation.gov.uk/ukpga/2015/9/pdfs/ukpga_20150009_en.pd. [Date accessed 08/05/2016]

Sims, M.E., Baker, B.W. and Hoesch, R.M. (2011) 'Tusk or bone? An example of ivory substitute in the wildlife trade', Ethnobiology Letters, 2, pp.40-44.

Stiles, D. (2004) 'The ivory trade and elephant conservation', Environmental Conservation, 31(4), 309-321.

Teagle A. (2015) Zimbabwe plans to sell baby elephants to global buyers

http://www.theguardian.com/world/2015/ian/15/-sp-zimbabwe-sell-62-baby-elephants-global-

$\underline{\text { buyers }}$

The Born Free Foundation. Retrieved from:

http://www.bornfree.org.uk/campaigns/elephants/campaign-action/ivory-trade/. [date accessed 02/04/2016]

TRAFFIC, The wildlife trade monitoring network analysis. Retrieve from http://www.traffic.org/bulletin/. [Date accessed 07/07/2016]

The Customs and Excise Managements Act 1979 (1979). Retrieved from:

http://www.legislation.gov.uk/ukpga/1979/2/contents. [Date accessed 08/05/2016]

Traffic.org website (2016) "About - Wildlife trade". Retrieved from: http://www.traffic.org/ [date accessed 04/03/2016] 
UNDOC. (2014). 'Guidelines on Methods and Procedures for Ivory Smuggling and Laboratory Analysis'. Vienna: United Nations. Retrieved from https://www.unodc.org/documents/Wildlife/Guidelines Ivory.pd Error! Hyperlink reference not valid.Error! Hyperlink reference not valid. [Date accessed 08/06/2016]

Walker, J. (2009). 'Ivory Ghosts: The White Gold of History and the Fate of Elephants'. Grove Press: New York.

Wittemyer, G., Northrup, J.M., Blanc, J., Douglas-Hamilton, I., Omondi, P. and Burnham, K.P (2014) Illegal killing for ivory drives global decline in African elephants. Proceedings of the National Academy of Sciences,111(36), pp.13117-13121.

wwf.panda.org.(2017). African elephants. [online] Available at:

http://wwf.panda.org/what_we_do/endangered_species/elephants/african_elephants/[Accessed 1 Feb. 2017].

Zane, D. (2016) Kenya's ivory inferno: Does burning elephant tusks destroy them? http://www.bbc.co.uk/news/world-africa-34313745 


\section{APPENDIX 1}

\section{U.K. Cases since 1992 involving prosecutions for the sale of ivory. Source: The National Wildlife}

\section{Crime Unit.}

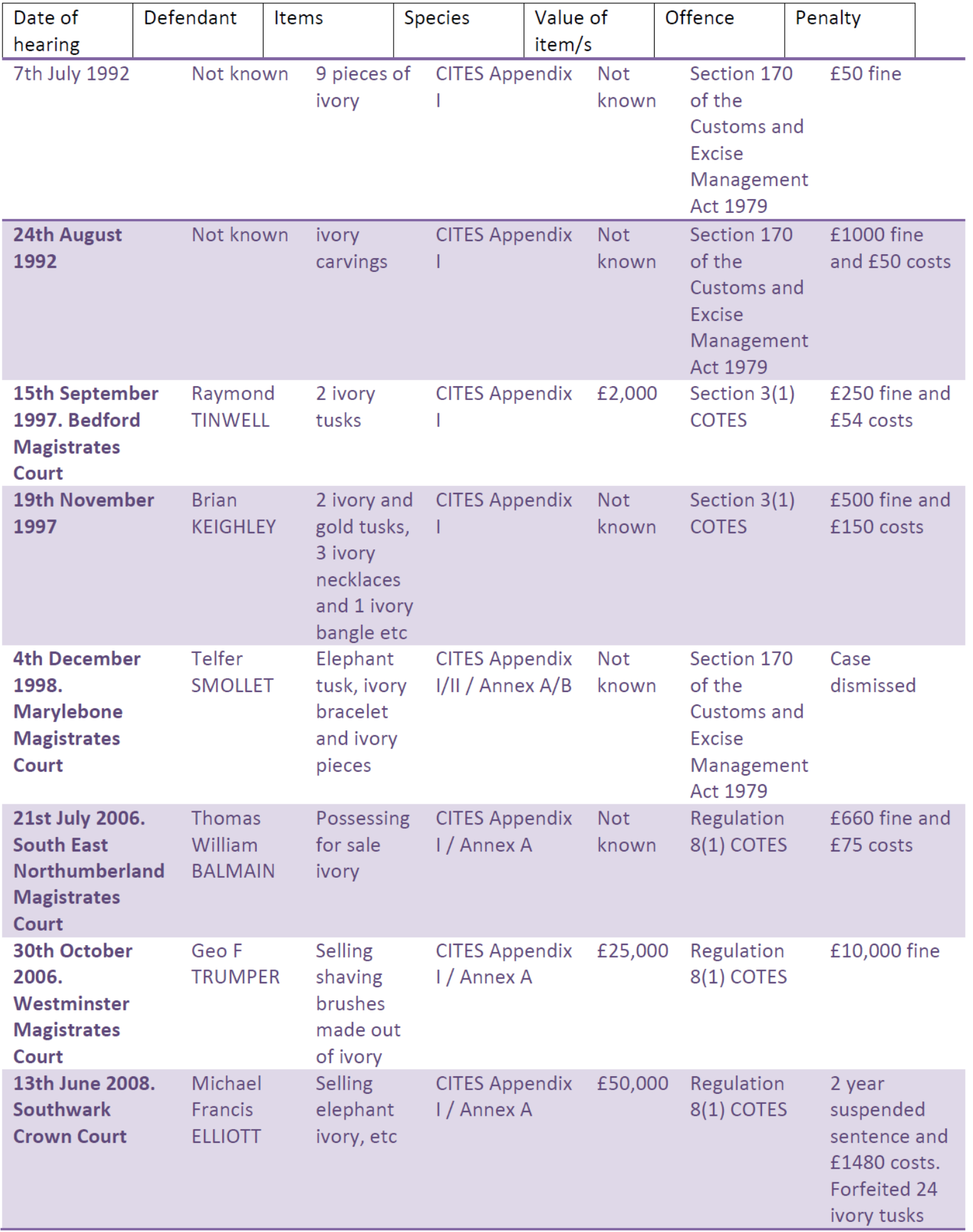




\begin{tabular}{|c|c|c|c|c|c|c|}
\hline & & & & & & $\begin{array}{l}\text { valued at } \\
£ 50,000\end{array}$ \\
\hline $\begin{array}{l}16 \text { October } 2009 . \\
\text { Luton Crown } \\
\text { Court }\end{array}$ & $\begin{array}{l}\text { Nicholas } \\
\text { NOONAN }\end{array}$ & $\begin{array}{l}\text { Sale of } \\
\text { ivory and } \\
\text { whales } \\
\text { teeth }\end{array}$ & $\begin{array}{l}\text { CITES Appendix } \\
\text { I / Annex A }\end{array}$ & $\begin{array}{l}\text { at least } \\
£ 10,000\end{array}$ & $\begin{array}{l}\text { Regulation } \\
\text { 8(1) COTES }\end{array}$ & $\begin{array}{l}10 \text { months } \\
\text { imprisonment }\end{array}$ \\
\hline $\begin{array}{l}10 \text { October } 2011 \\
\text { Basildon Crown } \\
\text { Court }\end{array}$ & $\begin{array}{l}\text { Francis } \\
\text { BENYURE }\end{array}$ & $\begin{array}{l}\text { Sale of } \\
\text { elephant } \\
\text { ivory }\end{array}$ & $\begin{array}{l}\text { CITES Appendix } \\
\text { I / Annex A }\end{array}$ & & $\begin{array}{l}\text { Regulation } \\
\text { 8(1) COTES }\end{array}$ & $\begin{array}{l}10 \text { months } \\
\text { sentence } \\
\text { suspended } \\
\text { for } 18 \\
\text { months, } 150 \\
\text { hours } \\
\text { community } \\
\text { service, } f 500 \\
\text { costs, 9am - } \\
6 p m \text { curfew } \\
\text { for } 4 \text { months }\end{array}$ \\
\hline $\begin{array}{l}3 \text { September } \\
2012 \text { Uxbridge } \\
\text { Magistrates } \\
\text { Court }\end{array}$ & $\begin{array}{l}\text { Colin } \\
\text { MCNEILL }\end{array}$ & $\begin{array}{l}\text { Illegally } \\
\text { attempting } \\
\text { to export } \\
\text { ivory }\end{array}$ & $\begin{array}{l}\text { CITES Appendix } \\
\text { I / Annex A }\end{array}$ & $\begin{array}{l}\text { Not } \\
\text { known }\end{array}$ & $\begin{array}{l}\text { Section } \\
170(2)(b) \text { of } \\
\text { the Customs } \\
\text { and Excise } \\
\text { Management } \\
\text { Act } 1979\end{array}$ & $\begin{array}{l}80 \text { hours } \\
\text { community } \\
\text { service, } 10 \\
\text { week curfew } \\
\text { order, } £ 500 \\
\text { costs }\end{array}$ \\
\hline $\begin{array}{l}27 \text { September } \\
2012 \text { Gloucester } \\
\text { Crown Court }\end{array}$ & Alex MAW & $\begin{array}{l}\text { Illegal } \\
\text { export of } \\
\text { elephant } \\
\text { ivory }\end{array}$ & $\begin{array}{l}\text { CITES Appendix } \\
\text { I/ Annex A }\end{array}$ & $£ 1,000$ & $\begin{array}{l}\text { Section } \\
170(2)(b) \text { of } \\
\text { the Customs } \\
\text { and Excise } \\
\text { Management } \\
\text { Act } 1979\end{array}$ & $\begin{array}{l}\text { Fined } £ 750 \\
\text { plus } £ 265 \\
\text { costs }\end{array}$ \\
\hline $\begin{array}{l}24 \text { January } 2014 \\
\text { Kingston Crown } \\
\text { Court }\end{array}$ & $\begin{array}{l}\text { Alick } \\
\text { BROWN }\end{array}$ & $\begin{array}{l}\text { selling and } \\
\text { keeping } \\
\text { for sale } \\
\text { ivory, etc }\end{array}$ & $\begin{array}{l}\text { CITES Appendix } \\
\text { I/ Annex A }\end{array}$ & $\begin{array}{l}\text { Not } \\
\text { known }\end{array}$ & $\begin{array}{l}\text { Regulation } \\
8(1) \text { COTES }\end{array}$ & $\begin{array}{l}\text { Fined } £ 750 \text {, } \\
£ 550 \text { costs, } \\
£ 75 \text { victim } \\
\text { surcharge }\end{array}$ \\
\hline $\begin{array}{l}14 \text { October } 2014 \\
\text { Ealing } \\
\text { Magistrates } \\
\text { Court }\end{array}$ & $\begin{array}{l}\text { Chiswick } \\
\text { Auctions } \\
\text { (William } \\
\text { ROUSE) }\end{array}$ & $\begin{array}{l}\text { Sale of one } \\
\text { carved } \\
\text { ivory } \\
\text { ornament }\end{array}$ & $\begin{array}{l}\text { CITES Appendix } \\
\text { I / Annex A }\end{array}$ & $£ 150$ & $\begin{array}{l}\text { Regulation } \\
8(1) \text { COTES }\end{array}$ & $\begin{array}{l}\text { Fined } £ 3,000, \\
£ 85 \text { costs, } \\
£ 120 \text { victim } \\
\text { surchage }\end{array}$ \\
\hline $\begin{array}{l}20 \text { October } 2014 \\
\text { Isleworth Crown } \\
\text { Court }\end{array}$ & $\begin{array}{l}\text { Sarah } \\
\text { WILKINSON }\end{array}$ & $\begin{array}{l}\text { Sale of one } \\
\text { carved } \\
\text { ivory } \\
\text { ornament }\end{array}$ & $\begin{array}{l}\text { CITES/Appendix } \\
\text { 1/Annex A }\end{array}$ & $£ 3000$ & $\begin{array}{l}\text { Regulation } \\
8(1) \text { COTES }\end{array}$ & Dismissed \\
\hline 23 May 2016 & Christie's & $\begin{array}{l}\text { Sale of one } \\
\text { carved } \\
\text { ivory } \\
\text { ornament }\end{array}$ & $\begin{array}{l}\text { CITES/Appendix } \\
\text { 1/Annex A }\end{array}$ & $\begin{array}{l}\text { Not } \\
\text { known }\end{array}$ & $\begin{array}{l}\text { Regulation } \\
8(1) \text { COTES }\end{array}$ & $\begin{array}{l}\text { Fined } \\
£ 3,250\end{array}$ \\
\hline
\end{tabular}

